\title{
INTRODUCTION TO SPECIAL ISSUE. SCIENCES OF THE NATION UNDER SOVIET RULE: ETHNOGRAPHY AND FOLKLORISTICS IN THE BALTIC REPUBLICS
}

\author{
INDREK JÄ̈̈TS \\ Researcher, PhD \\ Estonian National Museum \\ Muuseumi tee 2, 60532 Tartu, Estonia \\ e-mail: indrek@erm.ee
}

The five articles of this volume deal with the disciplinary histories of ethnography ${ }^{1}$ and folkloristics in the Baltic States. The articles grew out of presentations given on the panel entitled The Role of Ethnographic Studies in the Soviet Baltic Republics, at the AABS Conference at Stanford University in June 2018.

As disciplines studying culture and society, ethnography and folkloristics have always been closely intertwined with politics and ideology. In the course of the national movements of the late 19th and early 20th centuries, new meaning was attributed to traditional peasant culture, elements of which were used to build the modern Estonian, Latvian and Lithuanian nations - quite a typical process among the 'peasant peoples' of Central and Eastern Europe.

In the interwar Baltic Republics, ethnography and folkloristics together with linguistics and history were considered sciences of the nation that supported national identity. Yet, national schools of these disciplines were somewhat different in each country. It seems that ethnography and folkloristics were relatively strong both academically and institutionally in Estonia. In Latvia, folklore studies dominated and ethnography remained unprofessional until the late 1930s. Lithuanians, as a people with a glorious tradition of statehood of their own, probably did not need to rely on traditional peasant culture as much as Estonians and Latvians in their nation-building process and ethnography was not socially as important there as in Estonia. Several foreign countries were also important in influencing academic tradition in the Baltic States, for example Estonia had particular ties with Finland, Lithuania with Poland (although this relationship was somewhat complicated), and Sweden with both Estonia and Latvia. 
During the Soviet period, Baltic ethnographies and folkloristics were made a part of Soviet ethnography and folkloristics respectively, and subject to Marxist-Leninist theory. Ethnography was considered a branch of history in the Soviet Union of the day, whereas folkloristics was put together with linguistics and literature studies in Soviet academia.

It is obvious that the functions of ethnography and folkloristics in the Soviet Baltic republics were different for the central and regional communist authorities on the one hand, and for Baltic civic societies on the other. The communist authorities tried to place these disciplines under their ideological control and use them to propagate the regime and its achievements. They were rather successful in doing so until the mid-1950s.

The Soviet authorities and leading Soviet ethnographers from Moscow promoted study of contemporary society from the late 1940s. Old peasant culture - the main object of study of many Central and East European ethnographers, ethnologists and folklorists so far, was quickly disappearing and scholars had to find new approaches and fields of research. In the Soviet Union, ethnographers and folklorists had to show that they were helping to transform society according to the socialist model. They were expected to play their part in bringing up the new Soviet individual, promoting Sovietstyle internationalism, and ultimately building communism. Their task was not just to observe and analyse current social processes, but also to participate in the atheist struggle and in inventing new Soviet traditions, etc. Pressure from above to study contemporary Soviet society and show its policies (for example collectivisation, industrialisation) in a positive light was insistent.

However, after Stalin's death, the Soviet grasp relaxed a little and Baltic ethnographers and folklorists, many of them cherishing ethnic roots and particularity, were able gradually to return to the old channel of pre-war sciences of the nation. As a rule, many Estonian, Latvian and Lithuanian scholars preferred to study a relatively apolitical past - the late 19th and early 20th centuries. This was made possible thanks to some niches in Soviet ethnography and folkloristics, for example ethnogenesis studies and Soviet-style folklorism (styled folk costumes, staged folk songs, etc.). If official channels were too narrow, people were able to find other, less official channels to realise their interest in old peasant culture (for example, the regional studies movement in Lithuania).

Works on traditional peasant culture in local languages, especially if well illustrated, were in demand in the Soviet Baltic republics because they related to national identity and supported it. Many women were interested in 'national' handicraft and needed patterns and examples. People participating in folklore ensembles and song festivals needed folk costumes, songs, etc. Hence, ethnographers and folklorists served the interests of Estonian, Latvian, and Lithuanian civic societies rather than of the Soviet regime, especially from the 1960s. There were obligatory references to Lenin and other Communist classics in texts, but readers did not pay them much attention, they knew these references were just to hoodwink the authorities. 
Soviet time Baltic ethnographers and folklorists studied their own people, as a rule. Only some Estonians were persistently interested in their Finno-Ugric linguistic relatives (sc. kindred peoples). Estonians, Latvians and Lithuanians as 'socialist nationalities' and titular people of their republics were a fully legitimate object of study. This was in accord with Soviet national policy, contributing to the persistence of different national identities inside the Soviet Union by keeping up ethnic distinctions in many respects - the administrative structure of the state alongside ethnic criteria; the persistence of the category of 'nationality' in the Soviet passport; the census questions about 'nationality' and respective statistics; Soviet-style inter-nationalism. Nationalities were recognised and institutionalised in the Soviet Union. Promoting national culture, according to socialist ideas of course, was encouraged by the authorities. Baltic ethnographers and folklorists did their part, but not always as perfect socialists. There were grey areas and ideological control was not always strict.

Contact between Estonian, Latvian, and Lithuanian ethnographers and folklorists was initially mediated by Moscow. The Baltic republics were a single whole from Moscow's perspective and this fact promoted cooperation in the form of different meetings, conferences, joint publications and projects (ethnogenesis studies in the 1950s, the regional historical-ethnographic atlas in 1970s-1980s.) The language of communication was of course Russian at that time.

Contact between Soviet Baltic ethnographers and folklorists and their Western colleagues was almost absent until the late 1950s, and relatively sparse until the end of the Soviet period. Every Baltic nation had quite a significant academic community in exile, including ethnographers and folklorists, although contact with them was also limited, meaning that Baltic scholars were more or less isolated from disciplinary development behind the iron curtain. One can conclude that the Soviet period affected national schools of ethnography and folkloristics in the Baltic countries as a kind of preservative - mainly because of ideological restrictions and Marxist-Leninist dogma, but also because of the choices made by Baltic scholars themselves under the given circumstances.

The disciplinary histories of Estonian, Latvian and Lithuanian ethnography, especially in the Soviet period, have received very little international academic attention, although histories of Estonian and Latvian folkloristics are perhaps in a somewhat better position in this respect. However, I believe that these disciplines deserve attention because of their special status as sciences of the nation. Both ethnography and folkloristics have played quite important parts first in Estonian, Latvian and Lithuanian nation building, and then, during the Soviet period, in supporting national identity. I would say that these disciplines are very close to the essence of their respective nations, and perpetuated, at least partially, their blueprints. I believe that the Soviet period in Baltic ethnography and folkloristics is an interesting and important chapter in the European disciplinary history of the 20th century and deserves further investigation. 


\section{NOTES}

1 The branch of scholarship dealing with peoples and their cultures (mainly the material side) was called ethnography in the Soviet Union, including the Baltic republics, and the term is used here in that sense. 